\title{
"FOREST PRODUCTS RESEARCH IN CANADA"
}

\section{T. A. MCElHANNEy}

$\mathrm{I}$ $\mathrm{N}$ all branches of industry there is a steadily growing appreciation of the value of scientific research. The Dominion Government has been alive to this development and in many cases has led the way in providing facilities for scientific investigation in connection with primary industries concerned with the development of the country's resources. With reference to the forest products industries, that interest took practical form by the organization in 1913, in the Dominion Forest Service of the Department of the Interior of the Forest Products Laboratories. While, since that date, there have been periods-particularly during the war-when progress was retarded, nevertheless this organization has grown to nearly five times its original size. Its work is now conducted in three centres, viz,, the main laboratories in Ottawa, the Pulp and Paper division in Montreal and a branch laboratory in Vancouver, devoting attention to British Columbia problems which cannot be dealt with to advantage in the central laboratories in Ottawa.

The forest products industries of Canada are concerned with two broad general lines of activity: (1) the growing of the forest crop and (2) the conversion of this crop into commercial products. It is of the utmost importance that both phases be conducted with the greatest efficiency and with a full realization of the value of their permanence. The former of these is not a problem in which the laboratories are directly engaged, but with, respect to the latter it is a matter of considerable satisfaction to note the growing interest among lumbermen of the value of exact knowledge of the properties of their product, both from a manufacturing standpoint and in their trade extension activities.

In an industry such as the lumber industry, whose ramifications are so wide and in a country such as Canada where there has been so far, in general, an abundance of raw material, it is easy to understand why there has been, and in some cases still is, a high percentage of waste of material. Changing economic conditions are each year enhancing the value of wood, and this, together with the general development of public sentiment towards research, is no doubt responsible for the greater interest which is being taken in the curtailment of waste by wood-using industries. When consideration is given to the amount now being spent on forest products research in relation to the value of the products of the wood-using industries, it is reasonable to expect that there will be a steady increase in demand, not for government research alone but also for systematic investigation in the plants of the industry itself.

It should not be forgotten that the timber industry of Canada is second 
only to agriculture in the value of its primary products. Well over five hundred million dollars is invested in the pulp and paper industry, the annual value of its products exceeding one quarter billion dollars. The value of the annual production of primary products such as lumber, lath, shingles, etc., in Canadian mills exceeds $\$ 140,000,000$.

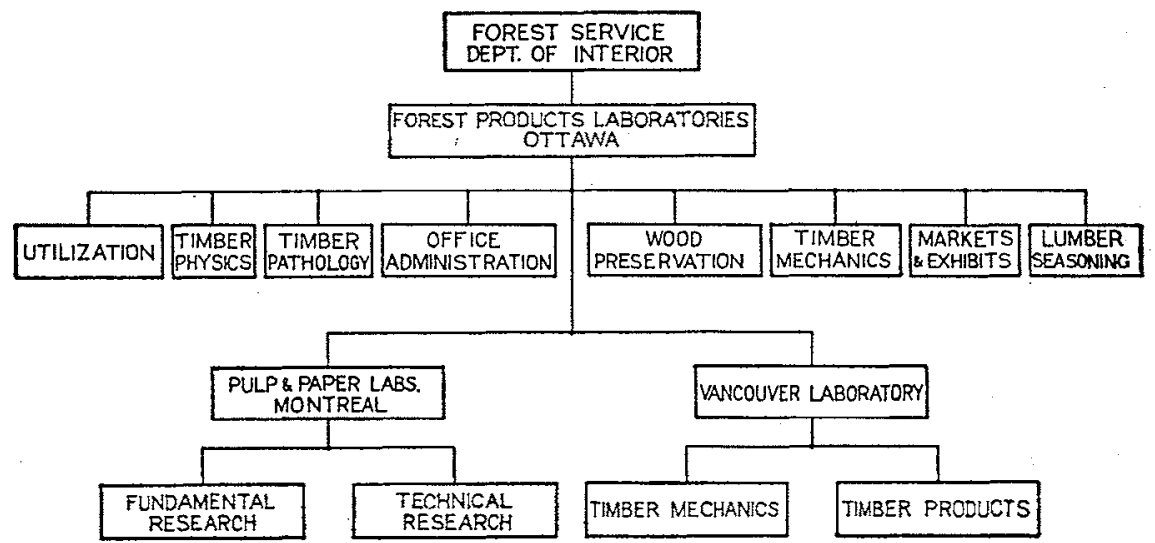

It has been already mentioned that there is still a great deal of waste in connection with the lumber industries. In some logging operations, particularly on the Pacific Coast, frequently over 25 per cent of the stand is left on the ground as it cannot be logged economically under present conditions with respect to methods of logging and markets. Losses sometimes as high as 20 per cent of its value are sustained in seasoning lumber. Nearly 50 per cent of the wood substance going into chemical pulp disappears in the mill effluent. Untreated timber is still being used for ties, poles, piling; bridge timber and other exposed uses, even though it is known that its period of service could be prolonged several times by the application of preservatives. Stain and decay is each year resulting in heavy losses to lumber manufacturers, blue stain in white pine yards in 1928 accounting for a loss of over one million dollars. The problem of curtailment of waste is not simply one of technique of process nor is it entirely one of economics. It is essentially a combination of both.

In order to provide facilities for investigation of forest products problems the laboratories are organized into a number of technical divisions with specialists in different branches of science in charge of corresponding divisions. The total staff of the laboratories is between ninety and one hundred, over thirty of whom are graduates in different branches of science. The operating divisions are: Pulp and Paper; Timber Mechanics; Wood Preservation; Lumber Seasoning; Timber Physics; Wood Utilization; Timber Pathology; Markets and Exhibits. 
The chart illustrates a little more clearly how the three laboratories func. tion. The technical work of the two branch laboratories operates in two divisions in each case. Only a brief sketch of the work of the divisions is possible in this paper.

\section{PULP AND PAPER.}

While the pulp and paper industry in Canada has developed at an almost phenomenal rate, methods of operation and standards in quality of pulp and paper and methods of testing, vary widely between plants. Wood is a very complex and variable substance consisting of cellulose and lignin. With the wood tissue is associated various gums, resins and oils varying in amount, quantity and quality with different species. The technical problems in the pulp and paper industry are therefore very diverse, very complicated, and very important.

The new pulp and paper laboratories in Montreal are, from the standpoint of experimental equipment, the finest of their kind in existence. Some valuable work has already been done in standardizing of methods of freeness testing which are in general use in Canada and to a very considerable extent in foreign countries. Considerable work has already been accomplished in connection with the pulping qualities of fre-killed wood, the pulping qualities of wheat straw, the use of clear water as a preservative for storing pulp, the manufacture of blotting paper from sulphite pulp, the use of Canadian talc in paper making and the use of magnesite in the sulphite process.

The work of the pulp and paper laboratory has been interrupted to a very considerable degree during the past two years while the new laboratories provided by the pulp and paper association were being erected. They are now, however, in full operation on a program of work which has been developed in close co-operation with the technical section of the pulp and paper association. This program includes studies in methods of testing and analyses of pulp and paper, determination of pulp quality, sulphite studies, printing qualities of paper, the use of kraft and soda pulps for rayon and many other studies of a similar nature.

\section{TIMBER MECHANICS.}

Basic data on the physical and mechanical properties of wood are fundamental to a study of wood uses. Without such data it is impossible to make an intelligent comparison of different species of native woods or of their properties with relation to those of foreign competing woods. Such studies have shown that Douglas fir has no superior among the softwoods of the world as a wood for heavy structural uses; they have shown remarkably low factors of shrinkage and expansion in white pine, which, combined 
with high durability make it an exceptionally valuable wood for a wide variety of uses; they have shown that Sitka spruce on account of its great strength with relation to weight, combined witht straightness of grain, is an especially valuable timber for aeroplane construction. Besides, there is a variety of uses for such information in specifications for structural timbers, in building codes and in many other ways. Possibly one of the most important uses to which such information has been applied, is in relation to foreign markets where choice of material is based on such information in lieu of practical experience in the use of new woods on the market. The work in timber mechanics has been especially valuable to the committees of the Canadian Engineering Standardization Association in drawing up specifications for poles, piling and other structural timbers.

\section{WOOD PRESERVATION.}

Wood, if completely submerged in water, or if kept in a continually dry condition, will last practically indefinitely. On the other hand, if exposed to conditions favorable to the action of wood-destroying fungi, it may decay very rapidly. In salt water it may fall a prey to marine borers or on land to wood-boring insects. In order to protect wood from such deterioration and thus prolong its life, exposed timbers such as telegraph and telephone poles, railway ties, bridge timbers, piling, cross arms, etc., are frequently treated with coal tar creosote, zinc chloride, sodium fluoride, zinc meta-arsenite or some other wood preservative. Through the development at the forest products laboratories of an incising machine for improving penetration and distribution of the preservative and the later acceptance of the principle of this machine, in commercial treating plants, railroads of Canada have saved over one million dollars through reduction of the amount of preservative required to obtain satisfactory treatment. Some work was done a few years ago on fire retardants for wood. Interest in this most important problem has recently revived, largely on account of increased competition from substitutes for shingles and timber, and through the inclusion in building codes in many cities of bylaws prohibiting wood construction.

\section{LUMBER SEASONING.}

Except for use in very rough or temporary work, lumber is seasoned to some degree before it is put in use. The more refined the use for which it is intended, the greater must be the care in seasoning. Unsatisfactory seasoning of timber is the most frequent source of complaint and claims between lumber dealers and users. Heavy losses are sustained in both air seasoning and kiln drying; some authorities placing such losses at $7 \%$ of the total value of all rough lumber cut.

While sufficient work has not yet been done by the laboratories in Canada 
to permit stating any such general figure, as already mentioned, instances have come to the attention of the laboratories of kiln drying losses as high as $20 \%$ of the value of the lumber, whereas in other instances where the importance of drying was more fully appreciated, lumber has been seasoned with losses so low as to be almost inappreciable. In one district where an intensive survey of dry kilns was made, losses were found aggregating about $\$ 1,125,000$ a year, although only about $30 \%$ of the cut of the district was kiln dried. In order to curtail these heavy losses, the laboratory is co-operating with lumbermen in special investigations and by the erection at the Ottawa and Vancouver laboratories of semi-commercial kilns to permit testing out drying schedules and demonstrating methods of operation.

\section{TIMBER PHY'SICS}

Large industries are very often based on very small and almost insignificant things. The rapid expansion of the pulp and paper industry in Canada may be said to be based on the remarkable qualities of the spruce fibre, Viewed from this standpoint the intensive study of the characteristics of the different woods is of the utmost importance. Wood structure has an important relation to the action of wood in drying, to its workability in the shop, to the penetration of the cooking liquor in manufacturing chemical pulp, to the resistance of wood to sound and heat transmission, and to the passage of an electric current.

WOOD UTILIZATION.

In order that the work of the more purely scientific divisions of the laboratory may be of practical service to the industry, it is essential that the laboratories keep in close touch with problems in the industries. It is considered that this may be more effectively done by the organization of a division for this particular purpose. Such problems as logging waste, sawmill waste, utilization of short length lumber, log flotation, uses of sawdust and planer mill shavings, new uses for wood, uses of species at present considered of little value, and other related problems will receive the attention of this division.

\section{TIMBER PATHOLOGY.}

Stains and decay in wood, in the forest, in the log, in the lumber yard and in service, are responsible for heavy annual losses. Some stains cause no appreciable reduction in the strength of the wood, but do result in reduction in grade and consequently of value, of occasionlly upwards of $\$ 10$ per thousand feet. This is particularly the case in blue stain of sapwood most prevalent in the pines, though not by any means confined to them. Red rot in jack pine, particularly for railway ties, has been a source of contention 
amongst interested parties. Slime in pulp mills and the action of fungi in stored wet pulp are sources of considerable trouble and loss. The study of such problems is taken care of in the timber pathology division, the work of which, as you will readily see, dovetails closely into the work of the timber mechanics, wood preservation, lumber seasoning and pulp and paper divisions.

\section{MARKETS AND EXHIBITS.}

Enquiries for data with reference to timber markets, especially export markets, have been steadily increasing, a large number of these originating through the activity of Canadian Trade Commissioners. Besides, the laboratories are frequently asked to advise concerning or participate in exhibits of wood products in Canada and in foreign exhibits, such as that in Antwerp in 1930 and in Buenos Aires in 1931. The laboratories have for several years encouraged in schools, particularly those with manual training departments, the study of the principal commercial timbers of Canada, and for this purpose have provided on request sets of samples of such woods properly identified, and labelled with the common and botanical names. The markets and exhibits work of the laboratory has become so important as to engage the whole attention of one officer.

\section{TECHNICAL SERVICE.}

Besides the projects planned and provided for in a year's program there is another field of laboratory activity which is of the utmost importance. Reference is made to the increasing degree to which the laboratories are functioning as a bureau of technical information for the lumber industry. Enquiries of Canadian and foreign origin are received on a wide variety of subjects. Some of these may be disposed of with little work. In other cases other authorities have to be consulted or special experiments conducted which involve a considerable expenditure of time. In the three laboratories, in the past year, over one thousand such requests were dealt with.

While in some fields of investigation reliable information is very meagre, in a great many other fields the Forest Products Laboratories are in advance of industry with their work. A great deal of information is available which is not being put to use to nearly the extent it might be. For this reason the answering of technical enquiries receives most careful attention. It is one of the principal media for making effective in a practical way the scientific work of the laboratories. 